Agro-Science Journal of Tropical Agriculture, Food, Environment and Extension

Volume 20 Number 3 (July 2021) pp. 104 - 109

ISSN 1119-7455

\title{
ERODIBILITY OF SOILS OF VARYING LAND UTILIZATION TYPES AND LITHOLOGIC MATERIALS IN CENTRAL SOUTHEASTERN NIGERIA
}

\author{
${ }^{* 1}$ Ahukaemere C.M., ${ }^{1}$ Onweremadu E.U. and ${ }^{2}$ Akamigbo F.O.R. \\ ${ }^{1}$ Department of Soil Science \& Technology, Federal University of Technology, Owerri, Nigeria \\ ${ }^{2}$ Department of Soil Science, University of Nigeria, Nsukka, Nigeria \\ ${ }^{* 1}$ Corresponding author email: mildredshine@yahoo.com
}

\begin{abstract}
Land use and parent materials influence behaviour of soils including responsiveness to erosion forces. The study investigated some soil properties related to erodibility in Abia and Imo States of Nigeria. Soil sampling was guided by geology and land use type. Random sampling technique was adopted in field studies. Two parent materials and three land use types were chosen for the study. In each parent material, three land use types were studied and in each land use, three soil profiles were sunk, described, and sampled using FAO procedure. Soil samples were subjected to laboratory analyses and data generated were analyzed using descriptive and inferential statistical tools. Results showed that sand sized particles ranged from 533.10 to $778.80 \mathrm{~g} \mathrm{~kg}^{-1}$ and this distribution differed significantly between parent materials. Silt content ranged from $141.70 \mathrm{~g} \mathrm{~kg}^{-1}$ in soils derived from false-bedded sandstone to $202.20 \mathrm{~g} \mathrm{~kg}^{-1}$ in shale-derived soils. Clay-sized particles ranged from $77.30 \mathrm{~g} \mathrm{~kg}^{-1}$ in soils derived from false-bedded sandstone to $264.70 \mathrm{~g} \mathrm{~kg}^{-1}$ in shale-derived soils, respectively. Water-stable aggregate ranged from 19.38\% in false-bedded sandstone to $29.23 \%$ in shale-derived soils. The DR (dispersion ratio) mean values ranged between 4.26 in shale and 8.46 in false-bedded sandstone, while the CDI (clay dispersion index) mean values ranged between 2.17 in shale and 8.41 in false-bedded sandstone, respectively. The forest soils had the lowest values of both DR (6.89) and CDI (6.40) for soils of the false-bedded sandstone, 3.85 and 1.59 for those derived from shale. The clay flocculation index (CFI) had mean of 2.16 in false-bedded sandstone and 7.83 in shale. In soils of the varying land use types, the mean soil $\mathrm{pH}\left(\mathrm{H}_{2} \mathrm{O}\right)$ ranged from 4.28 to 4.64 in soils derived from false-bedded sandstone and 4.27-5.57 in those derived from Shale. From the results, parent material and land use influenced soil erodibility parameters (water-stable aggregates, mean-weight diameter, DR, CDI, and CFI) and other soil properties such as organic carbon, bulk density, and moisture content.
\end{abstract}

Key words: Soil erosion, land use, parent material, macro aggregate, micro aggregate

\section{INTRODUCTION}

Soil erosion has contributed tremendously to land cover change in Nigeria especially in southeastern part comprising Imo, Abia, Anambra, Enugu, Ebonyi, Akwa-Ibom and Cross River States. The rapidly changing land cover characteristics can in most times be attributed to the degree of soil damage, devastation and degradation with soil erosion being a major degrading factor (Onweremadu, 2006). Natural and anthropogenic forces interact to cause soil erosion (Ubuoh et al., 2013) leading to varying levels of soil degradation- as responses of soils to erosive forces differ. Nonetheless, soil erosion results in loss of topsoil (Nyssen et al., 2004; Ezechukwu and Madubuike, 2015), alteration of biodiversity (Keesstra et al., 2018), depletion of soil flora and fauna (Lal, 2004), reduced agricultural productivity (Abdulfatai et al., 2014), declining soil fertility (Liu et al., 2013), increasing economic loss (Li et al., 2016) and general reduction in soil quality (Xu et al., 2016).
Erodibility characteristics of soils are related to lithologic materials (Ofomata, 1981) and land use (Akamigbo, 1999), parent materials, organic matter accumulation, soil aggregate stability (FAO, 2005), though this may be indirect through rate of weathering and basic cation release (Arbestain et al., 2007). On the other hand, land use influences aggregate stability (Oguike and Mbagwu, 2009) as nutrient removals cause changes in structural stability (Mill and Fey, 2003).

Cultivation destabilizes soil aggregation (Wakene, 2001) and this reduces soil moisture retentivity: implying more volumes of soil water will be available for erosive action. Particle size distribution which differs among parent materials (Ahukaemere, 2015; Irmak et al., 2007) influence aggregate stability indices of soils (Oguike and Mbagwu, 2009) and changes in organic matter content due to land use (Keesstra et al., 2018). The relevance of soil aggregate stability indices such as dispersion ratio (DR), clay flocculation index (CFI), 
mean-weight diameter (MWD) and water-stable aggregates (WSA) is obvious in sustaining soil's capacity to effectively perform vital ecosystem functions especially in Southeastern Nigeria with high rainfall amount, high precipitation rate and long duration falls. These erodibility indices including clay content, organic matter status and exchangeable sodium percentage are vital in regulating soil losses and soil quality (Kalhorw et al., 2017).

Given the spate of land degradation by soil erosion in Southeastern Nigeria coupled with increasing population amidst conflictive land use types and extreme climate aberrations, it becomes exigent to investigate some erodibility indices of selected soils of Southeastern Nigeria as they relate variation in lithologic origin and land use type. The major objective of this study was therefore to assess some erodibility indices of selected soils of Southeastern Nigeria in relation to parent material and land use.

\section{MATERIALS AND METHODS}

\section{Study Area}

The study was conducted at Umulolo Okigwe in Imo State and Itumbuzor, Bende in Abia State, both in Central Southeastern Nigeria (Lat. $4^{\circ} 40^{\prime}$ and $8^{\circ} 50^{\prime \prime}$ North and Long. $6^{\circ} 40^{\prime}$ and $8^{\circ} 15^{\prime \prime}$ East). Soils are derived from false-bedded sandstones (Umulolo Okigwe) and shale (Itumbuzor Bende). The study area lies within the humid tropics with annual rainfall ranging from 1800-2500 $\mathrm{mm}$ and characteristically bimodal having peaks at July and September with a dry spell in August. Annual temperature ranges from $26-30^{\circ} \mathrm{c}$ and a relative humidity of over $80 \%$ measured at 10.00 am during wet seasons. They have rainforest vegetation with plant species arranged in tiers, comprising emergent trees, overlying tree canopy types, shrubs and sun-hating plants at forest floor. Oil palm trees are dominant plant species in the area thus referred to as oil palm belt of Nigeria. Imo River is a major river in the area rising from Isuochi of Abia State passing through Umuna, Obowo, Mbaise and Ngor Okpala in Imo State, then through Ngwa and Ukwa (Abia State) and enters the Atlantic Ocean through Port Harcourt (River State). Major socioeconomic activities in the area include small scale farming, fishing, lumbering, gathering from the wild, artisanal activities and oil prospecting in some localities.

\section{Brief Description of the Sampling Sites}

Umulolo Okigwe ( $\left.5^{\circ} 52^{\prime} 20.5^{\prime \prime} \mathrm{N} ; 7^{\circ} 17^{\prime} 51.7^{\prime \prime} \mathrm{E}\right)$ is underlain by false-bedded sandstones known as Ajali Formation, and is characterized by lowlands with few gentle to undulating slopes. The sampling sites have secondary forest dominated by trees and shrubs, continuously cultivated lands and lands that have been under fallow for more than five years. Topsoils are sandy with few stones, pebbles and gravels. Itumbuzor $\left(5^{\circ} 50^{\prime} 37.5^{\prime \prime} \mathrm{N}, 7^{\circ} 68^{\prime} 04.2^{\prime \prime} \mathrm{E}\right)$ is in Bende area of Abia State, Nigeria. Its soils are derived from Bende-Ameki shale group. Soils are deep but moderately to poorly drained. Soils are grayish (5 YR 6/1, 5YR 5/1, 10YR 5/2 moist) and have mottles especially at endopedons. Soils are on plain to gentle and undulating slopes interspersed with some depressions. Soils are very sticky with trafficability constraints.

\section{Field Studies}

A reconnaissance visit preceded field studies which assisted in preparing for the latter. Geology map of the area guided location of sampling sites. Two parent materials namely, false-bedded sandstone and Bende-Ameki shale group were randomly selected for the study. In each lithologic group, three land use types were chosen at random for the investigation, and these land uses included secondary forest, cultivated and fallow lands. A transect of $150 \mathrm{~m}$ was cut in each of the land use types, and three soil profile pits were sunk $50 \mathrm{~m}$ apart, giving a total of 18 soil profile pits. Soil profile pits were described, and sampled using FAO (2006) guidelines. All soil profiles were georeferenced using handheld Global Positioning System (GPS) receiver (Garmin Ltd Kansas, USA). Field observations were made and recorded. Core samples were used to collect soil samples for bulk density determination.

\section{Laboratory Studies}

Soil samples were air-dried and sieved using $2.0 \mathrm{~mm}$ sieve in readiness for some laboratory analyses. Particle size analysis was performed using Bouyoucos hydrometer method (Gee and Or, 2002) while bulk density was measured by core method (Grossman and Reinch, 2002). Total porosity was calculated using a relationship between bulk density and particle density of the soil as follows:

$$
\mathrm{TP}=1-\frac{B D}{P D} \times 100
$$

where TP is percent total porosity, BD is bulk density, and PD is particle density assumed to be $2.65 \mathrm{Mg} \mathrm{m}^{-3}$. Soil moisture was measured gravimetrically thus:

$$
\text { Soil moisture }(\%)=\frac{W S-D S}{D S} \times 100 \ldots \ldots(2) ;
$$

where WS is weight of moist soil sample, and DS is weight of dry soil sample.

The following indices of microaggregate stability of the soil were also calculated using the relevant formulae (Igwe and Obalum, 2013):

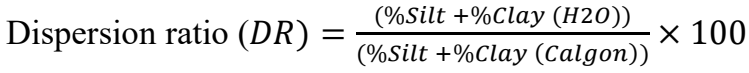

Clay dispersion index $(C D I)=\frac{\% \text { Clay }(\mathrm{H} 2 \mathrm{O}))}{\% \operatorname{Clay}(\text { Calgon }))} \times 100$

Clay flocculation index $(C F I)=100-$ CDI. 
Soil aggregate stability (WSA and MWD) was calculated after wet sieving done by the method of Kemper and Rosenau (1986). Soil $\mathrm{pH}$ was measured in 1:2.5 soil-water suspension (Thomas, 1996). Available phosphorus in the soil, extracted with Bray 2 solution (Olsen and Sommers, 1982), was determined in the supernatant solution using the molybdo-vanadate method (Murphy and Riley, 1962). Soil organic carbon was determined by wet digestion method described by Nelson and Sommers, 1996), while total nitrogen was determined by Kjeldahl digestion method (Bremner and Mulvaney, 1982).

\section{Data Analysis}

Soil data were subjected to analysis of variance to test differences in soil properties in relation to land use, for significantly different parameters $(p<0.001$, $0.01,0.05)$. Means were separated using Least Significant Difference (LSD) while statistical difference between the two parent materials was ascertained using $t$-test. Correlation analysis was done to determine the relationship between soil properties.

\section{RESULTS AND DISCUSSION}

\section{Physical Properties of the Soils}

in Relation to Erosion Hazard

Table 1 shows physical properties of soils, with sandsized particle sizes dominant over other sizes irrespective of parent material and land use type. Sand-sized particles ranged from 533.10 to $778.80 \mathrm{~g} \mathrm{~kg}^{-1}$ and this distribution differed significantly $(p<0.05)$ between parent materials. Significant differences were also recorded in other particle sizes. Silt content ranged from 141.70 to $202.20 \mathrm{~g} \mathrm{~kg}^{-1}$ with false-bedded sandstone having minimum value $\left(141.70 \mathrm{~g} \mathrm{~kg}^{-1}\right)$ and shale-derived soils having the maximum value $\left(202.20 \mathrm{~g} \mathrm{~kg}^{-1}\right)$. Clay-sized particles ranged from 77.30 to $264.70 \mathrm{~g} \mathrm{~kg}^{-1}$ with false-bedded sandstones and shale-derived soils having minimum and maximum values, respectively. Clays are lighter than other particle sizes thus readily eroded on the soil surface if other conditions are met.

Land use did not significantly alter the distribution of particle sizes. Results on particle size distribution show that in a short period of time, land use may not alter soil texture being an inherent property of soils, but this can change with prolonged weathering over a long chronological space, indicating the need for soil conservation irrespective of soil textural class. Similar textural behaviour was earlier reported by Denton et al. (2017). Total porosity of soils varied significantly $(p<0.001)$ between parent materials and among land use types with mean values ranging from $54.16 \%$ (shale) to $59.90 \%$ (false-bedded sandstone). Across the three different land use types studied, forested soils had significantly higher pore spaces than the cultivated and fallow soils. Other factors are assumed constant, soils of the false-bedded sandstone and forest record more infiltration thereby minimizing runoff build-up. Using moisture content, results showed significant $(p<0.001)$ differences among soil groups with shale soils having maximum gravimetric moisture content of $12.49 \%$ and false-bedded sandstone having minimum value of $9.09 \%$. It would be expected that the higher the moisture content the greater tendency of soil water to accumulate for movement via soils, but clays hold water tenaciously due to high content of micropores such that the water contained there may not be available for erosion. On the other hand, large macropores dominate the false-bedded sandstone; so, the soils hardly erode unless an imperious layer lies proximal to the soil surface. Generally, land use influenced bulk density, total porosity, moisture content, WSAs and MWD at $p<0.001$, indicating impact of land use on these erodibility indices (Table 1). Obalum et al. (2013) reported that land use influenced soil bulk density and permeability; Ahukaemere et al. (2016) reported that fallow period influenced soil bulk density and moisture content.

Also, significant $(p<0.001)$ differences existed for the MWD of soils, ranging from $0.46 \mathrm{~mm}$ (cultivated soils) to $1.48 \mathrm{~mm}$ (forest) as well as for WSA of soils with minimum value of $12.58 \%$ (cultivated soils) and maximum value of $27.37 \%$ (forest) in soils derived from the false-bedded sandstone. In shale-derived soils, significant $(p<0.001)$ differences were recorded for MWD of soils, ranging from $0.79 \mathrm{~mm}$ (cultivated) to $2.07 \mathrm{~mm}$ (forest) and WSA of soils with minimum value of $19.00 \%$ (cultivated soils) and maximum value of $41.40 \%$ (forest) in soils derived from the shale. Higher values of WSAs in the shale-derived soils could be due to higher content of clay in these soils. As earlier posited, soil aggregation is dependent on clay, silt, and organic carbon content as well as ionic bridging among other factors (Bromik and Lal, 2005). Expectedly, soils of forest land use had significantly $(p<0.001)$ higher stable aggregates than other land use types irrespective of lithologic origin (Table 1), suggesting least erodibility. Tillage and removal of nutrients (Mill and Fey, 2003), tillage disturbances (Oguike and Mbagwu, 2009), differences in organic carbon content (Onweremadu and Okoli, 2017) as well as intensity of tillage (Lal, 2004) may have caused these differences in aggregate stability.

The DR and CDI differed significantly between the parent materials (Figure 1) and among the three land use types. The DR mean values ranged between 4.26 in shale and 8.46 in false-bedded sandstone while the CDI mean values ranged between 2.17 in shale and 8.41 in false-bedded sandstone, respectively. 
Influence of Land Use and Lithologic Material on Soil Erodibility Central Southeastern Nigeria 107

Table 1: Physical properties and erodibility indexes of soils of the different parent materials and land use types

\begin{tabular}{|c|c|c|c|c|c|c|c|c|c|c|c|}
\hline Land uses & $\begin{array}{l}\text { Sand } \\
\left(\mathrm{g} \mathrm{kg}^{-1}\right)\end{array}$ & $\begin{array}{l}\text { Silt } \\
\left(\mathrm{g} \mathrm{kg}^{-1}\right)\end{array}$ & $\begin{array}{l}\text { Clay } \\
\left(\mathrm{g} \mathrm{kg}^{-1}\right)\end{array}$ & $\begin{array}{l}\mathrm{BD} \\
\left(\mathrm{g} \mathrm{cm}^{-3}\right)\end{array}$ & $\begin{array}{l}\mathrm{TP} \\
(\%)\end{array}$ & $\begin{array}{l}\mathrm{MC} \\
(\%)\end{array}$ & $\begin{array}{l}\text { WSA } \\
(\%)\end{array}$ & $\begin{array}{l}\text { MWD } \\
(\mathrm{mm})\end{array}$ & DR & CDI & CFI \\
\hline \multicolumn{12}{|c|}{ False-bedded sandstone } \\
\hline Cultivated & 781.80 & 148.00 & 70.20 & 1.12 & 57.78 & 8.26 & 12.58 & 0.46 & 9.35 & 9.87 & 1.87 \\
\hline Forest & 775.10 & 141.30 & 79.10 & 0.93 & 64.45 & 10.02 & 27.37 & 1.48 & 6.89 & 6.40 & 3.60 \\
\hline Fallow & 779.60 & 135.80 & 82.40 & 1.13 & 57.49 & 8.97 & 18.20 & 0.81 & 9.15 & 8.98 & 1.02 \\
\hline LSD & NS & NS & NS & $0.08 * * *$ & $2.83 * * *$ & $1.21 * * *$ & $2.92 * * *$ & $0.19 * * *$ & $1.21 * *$ & $1.13 * *$ & $0.14 * *$ \\
\hline Mean & $778.80 \mathrm{a}$ & $141.70 \mathrm{a}$ & $77.30 \mathrm{a}$ & $1.06 \mathrm{a}$ & $59.90 \mathrm{a}$ & $9.09 \mathrm{a}$ & $19.38 \mathrm{a}$ & $0.92 \mathrm{a}$ & $8.46 \mathrm{a}$ & $8.41 \mathrm{a}$ & $2.16 \mathrm{a}$ \\
\hline \multicolumn{12}{|l|}{ Shale } \\
\hline Forest & 532.20 & 212.00 & 255.80 & 1.08 & 60.89 & 14.80 & 41.40 & 2.07 & 3.85 & 1.59 & 8.41 \\
\hline Fallow & 550.00 & 184.20 & 265.80 & 1.28 & 49.99 & 12.84 & 27.30 & 1.18 & 4.93 & 2.41 & 7.59 \\
\hline LSD & NS & NS & NS & $0.09 * * *$ & $4.036^{* * *}$ & $1.49 * * *$ & $5.27 * * *$ & $0.306^{* * *}$ & $0.72 * *$ & $0.32 * *$ & $0.95 * *$ \\
\hline Mean & $533.10 b$ & $202.2 b$ & $264.7 b$ & $1.20 \mathrm{~b}$ & $54.16 \mathrm{~b}$ & $12.49 \mathrm{~b}$ & $29.23 b$ & $1.35 \mathrm{~b}$ & $4.26 \mathrm{~b}$ & $2.17 \mathrm{~b}$ & $7.83 \mathrm{~b}$ \\
\hline
\end{tabular}

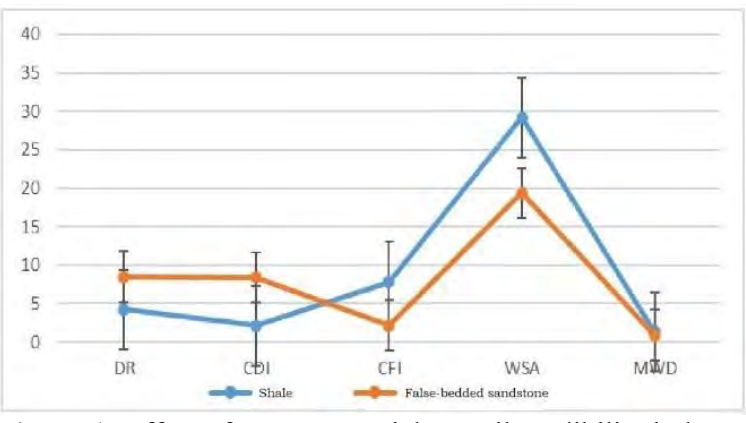

Figure 1: Effect of parent material on soil erodibility indexes

The forest soils had the least values of both DR (6.89) and CDI (6.39) for soils of the false-bedded sandstone, 3.85 and 1.58 for forest soils derived from shale. The CFI had mean of 2.16 in false-bedded sandstone and 7.82 in shale. Across the parent materials, forest soils had significantly higher CFI than fallow and cultivated soils. High CFI, low DR and CDI recorded in forest soils and soils derived from shaley lithology indicated least erosion hazards. The higher the DR and CDI, the more the ability of the soil to disperse, while the higher the CFI the better aggregated the soil (Basga et al., 2018). Igwe and Udegbunam (2008) opined that CFI is a very good micro-aggregate index for predicting soil erodibility. According to Igwe et al. (1995), CFI ranked highest among other micro- and macro-aggregate indices in predicting potential soil loss in some soils of southeastern Nigeria.

\section{Chemical Properties of Soils}

The $\mathrm{pH}$ of soils was acidic in the two parent materials. In soils of the varying land use types, the mean $\mathrm{pH}\left(\mathrm{H}_{2} \mathrm{O}\right)$ values ranged from 4.28-4.64 in soils formed from false-bedded sandstone and 4.27-5.57 in those derived from shale (Table 2). Abua et al. (2010) and Iwara et al. (2011) reported similar results in some soils of Southeastern Nigeria. From the result, soil reaction differed significantly across the parent materials and land use types which could be a consequence of composition of the lithologic material, land use practices and topography of the areas. The organic carbon contents of soils differed significantly across the soils studied. The organic carbon contents of soils ranged between 17.59 and $22.08 \mathrm{~g} \mathrm{~kg}^{-1}$. In the different land use types, organic carbon content was within the ranges of $12.03-38.47 \mathrm{~g} \mathrm{~kg}^{-1}$ in falsebedded sandstone and 1.22-28.64 $\mathrm{g} \mathrm{kg}^{-1}$ in shale. From the results, forest soils contained significantly higher proportion of organic carbon than other land use types. The differences in organic carbon content may be linked to the heterogeneity of land use pattern and management practices. Soil organic carbon has been reported to decrease with vegetation density among land use types (Obalum et al., 2012). The low values in the cultivated land could be due to agricultural practices that favour rapid decomposition. Conversion of natural forest to cultivated land modifies the microclimate with different canopy cover and litter fragmentation (Senjobi, 2007).

Table 2: Chemical properties of soils of the different land use types

\begin{tabular}{|c|c|c|c|c|c|c|c|c|c|}
\hline Land Uses & $\mathrm{pH}-\mathrm{KCl}$ & $\mathrm{pH}-\mathrm{H}_{2} \mathrm{O}$ & $\begin{array}{l}\mathrm{OC} \\
\left(\mathrm{g} \mathrm{kg}^{-1}\right)\end{array}$ & $\begin{array}{l}\text { Total nitrogen } \\
\left(\mathrm{mg} \mathrm{kg}^{-1}\right)\end{array}$ & $\begin{array}{l}\text { AvP } \\
\left(\mathrm{mg} \mathrm{kg}^{-1}\right)\end{array}$ & $\begin{array}{l}\text { TEB } \\
\left(\mathrm{cmol} \mathrm{kg}^{-1}\right)\end{array}$ & $\begin{array}{l}\text { Exch. acidity } \\
\left(\mathrm{cmol} \mathrm{kg}^{-1}\right)\end{array}$ & $\% \mathrm{ESP}$ & $\begin{array}{l}\% \text { Base } \\
\text { saturation }\end{array}$ \\
\hline \multicolumn{10}{|c|}{ False-bedded sandstone } \\
\hline Cultivated & 3.73 & 4.62 & 12.03 & 3.60 & 14.91 & 4.72 & 0.90 & 0.78 & 83.58 \\
\hline Forest & 3.64 & 4.64 & 38.47 & 14.33 & 19.50 & 4.86 & 2.38 & 2.12 & 65.85 \\
\hline Fallow & 3.73 & 4.28 & 15.74 & 4.06 & 18.26 & 3.69 & 2.87 & 0.40 & 56.70 \\
\hline LSD & NS & $0.31 *$ & $7.23 * * *$ & $2.48 * * *$ & NS & NS & $0.53 * * *$ & $0.81 * * *$ & $10.7 * * *$ \\
\hline Mean & $3.69 \mathrm{a}$ & $4.52 \mathrm{a}$ & 22.08 & 7.33 & $17.56 \mathrm{a}$ & $4.43 \mathrm{a}$ & $2.05 \mathrm{a}$ & $1.10 \mathrm{a}$ & $68.71 \mathrm{a}$ \\
\hline \multicolumn{10}{|l|}{ Shale } \\
\hline Cultivated & 3.63 & 4.38 & 11.22 & 2.01 & 22.92 & 2.98 & 0.84 & 0.73 & 78.80 \\
\hline Forest & 3.72 & 5.57 & 28.64 & 10.49 & 17.20 & 6.60 & 0.63 & 1.63 & 86.70 \\
\hline Fallow & 3.70 & 4.24 & 12.89 & 3.95 & 20.42 & 4.72 & 0.19 & 0.23 & 90.20 \\
\hline LSD & NS & $0.26 * * *$ & $5.10 * * *$ & $4.356 * *$ & $3.19 * * *$ & $2.346^{*}$ & NS & $1.19^{*}$ & $8.67 *$ \\
\hline Mean & $3.69 \mathrm{a}$ & $4.37 \mathrm{~b}$ & 17.58 & 5.48 & $20.85 b$ & $5.83 \mathrm{~b}$ & $0.55 b$ & $0.86 \mathrm{~b}$ & $91.42 b$ \\
\hline
\end{tabular}

OC - organic carbon, TN - total nitrogen, AvP - available P, TEB - total exchangeable bases, ESP - exchangeable sodium percentage

LSD - least significant difference, $* * * p<0.001, * * p<0.01, * p<0.05$, NS - not significant. Means with same lower-case letters are similar. 
From the results, it was deduced that forest ecosystems appear to be the most conducive climatic environment for maximum organic carbon accumulation, thus aid in maintaining good soil aggregation, reduced erodibility and soil compaction.

Results of correlation show significant $(p<0.001)$ relationships between organic carbon and bulk density in soils derived from false-bedded sandstone and shale $\left(r^{2}=0.54\right.$ and 0.81 , respectively) (Figure 2), implying that as organic carbon increases in the soils, bulk density decreases due to increases in macroaggregation (Onweremadu and Okoli, 2017) and water infiltration into the soils (Attah, 2010). Organic carbon also had significant $(p<0.001)$ positive relationships with clay, CFI and WSA in soils of the false-bedded sandstone $\left(r^{2}=0.513,0.601\right.$ and 0.626 , respectively) and shale $\left(r^{2}=0.578,0.611\right.$ and 0.646 , respectively).

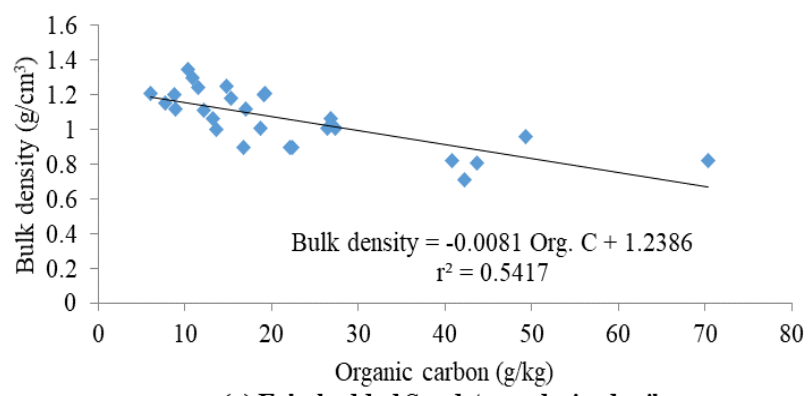

(a) Falsebedded Sandstone-derived soils

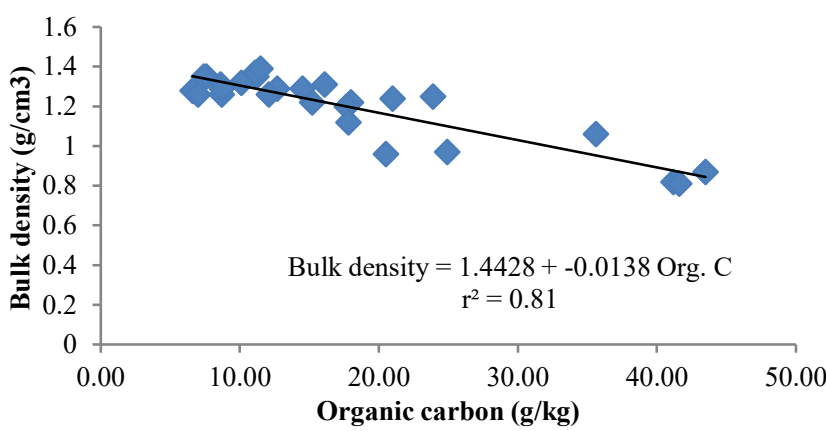

Figure 2: Relationship between soil organic carbon and bulk density for the (a) False-bedded sandstone-derived soils and (b) Shale-derived soils

\section{CONCLUSION}

The sand, silt and clay fractions differed significantly between parent materials. Parent material and land use influenced soil erodibility indices namely bulk density, total porosity, moisture content, and organic carbon, as well as macro- and micro-aggregate stability, indicating impact of lithological material and land use on these erodibility indices. Soils derived from shale and soils under forest land use had higher WSA, MWD and CFI than soils derived from falsebedded sandstone and those under fallow and continuous cultivation. Also, forest soils had higher $\mathrm{pH}$ values and organic carbon than other land use types. Based on this finding, we suggest further research on erodibility capacity of soils of other parent materials and land uses in the tropics.

\section{REFERENCES}

Abdulfatai I.A., Okunlola I.A., Akandle W.G., Momoh L.O. and Ibrahim K.O. (2014). Review of gully erosion in Nigeria: Causes, impact and possible solutions. $J$. Geosci. Geomat. 2 (3), 125-129

Abua M.A., Offiong R.A., Iwara A.I. and Ibor U.W. (2010). Impact of newly constructed roads on adjoining soil properties in Tinapa resort, Southeastern Nigeria. Ann. Human. Dev. Stud., 1 (1), 176-184

Ahukaemere C.M. (2015). Sequestration and Dynamics of Carbon and Nitrogen in Soils of Dissimilar Lithologies under Different Land Use Types in South-East Nigeria. $\mathrm{PhD}$ Thesis, Department of Soil Science \& Technology, Federal University of Technology, Owerri, Nigeria, p. 266

Ahukaemere C.M., Onweremadu E.U., Ndukwu B.N. and Okoli N.H. (2016). Pedogenesis of two lithologically similar soils under vegetation of contrasting features in Ohaji, Southeastern Nigeria. Agro-Science, 15 (3), 34-40

Akamigbo F.O.R. (1999). Influence of land use on soil properties of the humid tropical agro-ecology of Southeastern Nigeria. Nig. Agric. J., 30, 59-70

Arbestain M., Pardo-Lorenzo R., Gonzalez-Arias A., et al. (2007). Effect of parent material and pedogenic processes on the distribution, forms and dynamic of organic carbon in forest ecosystem in NW Spain: A biochemical approach. In: Munoz S.I. (ed.), Ecology Research Progress (pp. 117-153), Nova Science Publishers Inc.

Attah L.E. (2010). Physico-chemical characteristics of the rhizosphere soils of some cereal crops in Ambo Wirreda, West Shoa, Ethiopia. Maejo Int. J. Sci. Technol., 4 (01), 93-100

Basga S.D., Tsozué D., Temga J.P., Balna J. and Nguetnkam J.P. (2018). Land use impact on clay dispersion/flocculation in irrigated and flooded vertisols from Northern Cameroon. Int. Soil Water Conserv. Res., 6 (3), 237-244

Bremner J.M. and Mulvaney C.S. (1982). Total-nitrogen. In: Page A.L., Miller R.H. and Keeney D.R. (eds), Methods of Soil Analysis, Part 2 (pp. 595-624). American Society of Agronomy, Madison W1

Bronick C. and Lal R. (2005). Soil structure and management: A review. Geoderma, 124, 3-22

Denton O., Ogunkunle A. and Fademi I. (2017). Variations in soil properties as influenced by land use and soil depth in derived savannah ecology of Southwestern Nigeria. Nig. J. Soil Sci., 27, 345-357

Ezechukwu I.A. and Madubuike C.N. (2015). Environmental impact assessment of gully erosion in Umuoji, Idemili North LGA in Anambra State. Int. J. Eng. Sci., 4 (19), 44-53

FAO (2005). The importance of soil organic matter. Key to drought resistant soil and sustained food production. Food and Agriculture Organization (FAO) Soils Bulletin, No. 80, p. 78 
FAO (2006). Guidelines for soil description (4 $4^{\text {th }}$ ed.) Food and Agriculture Organization (FAO) of the United Nations, $97 \mathrm{pp}$.

Gee G. and Or D. (2002). Particle size analysis. In: Dane J.H. and Topp G.C. (eds.), Methods of Soil Analysis, Part 4: Physical Methods (pp. 255-293). Soil Science Society of America Book Series No. 5, Madison W1

Grossman R.B. and Reinch T.G. (2002). Bulk density and linear extensibility. In: Dane J.H. and Topp G.C. (eds.), Methods of Soil Analysis Part 4: Physical Methods (pp. 201-228). Soil Science Society of America Book Series No. 5, Madison Wisconsin

Igwe C.A. and Obalum S.E. (2013). Microaggregate stability of tropical soils and its roles on soil erosion hazard prediction, Advances in Agrophysical Research (Chap. 8), Stanisław Grundas (Ed.), ISBN: 978-953-511184-9, InTech, DOI: 10.5772/52473. Available at: http: //www.intechopen.com/books/advances-in-agrophysicalresearch/ microaggregate-stability-of-tropical-soils-and-its-roles-on-soilerosion-hazard-prediction

Igwe C.A. and Udegbunam O.N. (2008). Soil properties influencing water-dispersible clay and silt in an Ultisol in Southeastern Nigeria. Int. Agrophys., 22, 319-329

Igwe C.A., Akamigbo F.O.R. and Mbagwu J.S.C. (1995). The use of some soil aggregate indices to assess potential soil loss in soils of Southeastern Nigeria. Int. Agrophys., 9, 95-100

Irmak S., Surueu A.K. and Aydogdu L.H. (2007). Effects of different parent material on the mineral characteristics of soils in the arid region of Turkey. Pak. J. Biol. Sci., 10 (4), 528-536

Iwara A.I., Ogundele F.O., Ibor U.W., Arrey V.M. and Okongor O.E. (2011). Effect of vegetation adjoining tourism facilities on soil properties in the tourism enclave of Cross River State. Res. J. Appl. Sci., 6 (4), 276-281

Kalhorw S.A., Xuetuan X., Wnyuan C., Rui H. Sajjad R. and Kang D.A (2017). Effects of different land use systems on soil aggregation: A case study of the loess Plateau, Northern China. Sustainability, 1349

Keesstra S., Nunes J., Novana A., et al. (2018). The superior effect of nature-based solutions in land management for enhancing ecosystem services. Sci. Total environ. 610, 997-1009

Kemper W.D. and Rosenau R.C. (1986). Size distribution of aggregates. In: A. Klute (ed.), Methods of Soil Analysis, Part 1, $2^{\text {nd }}$ ed. (pp. 425-442). Agron. Monogr., No. 9, Madison Wisconsin

Lal R. (2004). Soil degradation by erosion. Land Degrad. Dev., 12, 519-539

Li Y., Jiwo J., Wang Z., et al. (2016). Effects of revegetation on soil organic carbon storage and erosion induced carbon loss under extreme rainstorms in the hill and gully region of the loess Plateau. Int. J. Environ. Res. Public Health, 13, 456

Liu H.U., Zlang T.Y., Liu B.Y., Liu G. and Wilson G. (2013). Effects of gully erosion and gully filling on soil depth and crop production in the black soil region, Northeast China. Environ. Earth Sci., 68, 1723-1732

Mill A.G. and Fey M.V. (2003). Declining soil quality in South Africa: Effects of land use on soil organic matter and surface crusting. South Afr. J. Sci., 99, 429-436

Murphy L. and Riley J. (1962). Modified single solution method for the determination of phosphate in natural water. Ann. Chem. ACTA, 27, 31-36
Nelson D.W. and Sommers L.E. (1996). Total carbon, organic carbon and organic matter. In: Methods of Soil Analysis, Part 3: Chemical Methods (p. 103). Soil Science Society of America Book Series

Nyssen J., Poesen J., Moeyersons J., et al. (2004). Human impact on the environment in the Ethiopian and Eriterean Highlands: A state of art. Earth Sci. Rev., 64 (3-4), 273-320

Obalum S.E., Oppong J., Igwe C.A., Watanabe Y. and Obi M.E. (2013). Spatial variability of uncultivated soils in derived savanna. International Agrophysics, 27 (1), 57-67. DOI: 10.2478/v10247-012-0068-9

Obalum S.E., Watanabe Y., Igwe C.A., Obi M.E. and Wakatsuki T. (2012). Carbon stock in the solum of some coarse-textured soils under secondary forest, grassland fallow and bare footpath in the derived savanna of southeastern Nigeria. Soil Research, 50 (2), 157-166. https://doi.org/10.1071/SR11096

Ofomata, G.E.K. (1981). Actual and potential erosion in Nigeria and measures for control. Soil Science Society of Nigeria Special Monograph, 1, 151-165

Oguike P.C and Mbagwu J.S. (2009). Variations in some physical properties and organic matter content of soils of coastal plain sands under different land use types. World J. Agric. Sci., 5 (1), 63-69

Onweremadu E.U. (2006). Application of Geographic Information Systems onto Soils, Land Use and SoilRelated Environmental Problems in Southeastern Nigeria. PhD Thesis, Department of Soil Science, University of Nigeria, Nsukka, Nigeria, p. 330

Onweremadu E.U. and Okoli N.H. (2017). Aggregation, tillage and carbon sequestration in soils of dissimilar lithology. Nig. J. Soil Sci., 27, 307-315

Olsen S.R., Sommers L.E. (1982). Phosphorus. In: Page A.L., Miller R.H. and Keeny D.R. (eds.), Methods of Soil Analysis, Part 2: Chemical Properties (2 ${ }^{\text {nd }}$ ed.) (pp. 15-72). Agronomy Monograph No. 9, American Society of Agronomy, Madison Wisconsin

Senjobi B.A. (2007). Comparative Assessment of the Effect of Land Use and Land Type on Soil Degradation and Productivity in Ogun State, Nigeria. PhD Thesis, Department of Agronomy, University of Ibadan, Ibadan, Nigeria, p. 161

Thomas G.W. (1996). Soil pH and soil acidity. In: Sparks, D.L., Page A.L., Helmke P.A. et al. (eds.), Methods of Soil Analysis, Part 3: Chemical Methods (pp. 475-490) Soil Science Society of America Book Series No. 5, Madison Wisconsin

Ubuoh E.A., Akhionbere W.N., Onweremadu E. and Onifade O.A. (2013) characterization of soil quality in erosion-prone environmental of Ukpor, Nnewi-South LGA, Anambra State, Nigeria. Int. J. Adv. Appl. Sci., 2 (1), 1-8

Wakene N. (2001). Assessment of Important Physiochemical Properties of Nitosols and Different Management Systems in Bako Area, Western Ethiopia. MSc Thesis, Alemaya, Ethiopia

Xu M., Li Q. and Wilson G. (2016). Degradation of soil physiochemical quality by ephemeral gully erosion on sloping cropland of a hilly loess Plateau, China. Soil Till. Res., 155, 9-18 